\title{
How to assess chemically defined media and feeds from 9 suppliers on $\mathrm{CHO}$ cells producing $\mathrm{mAb}$
}

\author{
Aurore Polès-Lahille*, Margaux Paillet, Aurélie Da Silva, Nora Kadi, Eric Basque, Flavien Thuet, David Balbuena, \\ Sébastien Ribault \\ From 23rd European Society for Animal Cell Technology (ESACT) Meeting: Better Cells for Better Health \\ Lille, France. 23-26 June 2013
}

\section{Introduction}

Mammalian cell culture medium development has widely evolved in recent years. The use of hydrolysates as serum replacement has led to process variability due to lot-tolot variations. The undefined composition of these media could also increase the process optimization timelines, sometimes with limited impact on process performances. With the reduction of process development activities for preclinical and Phase I studies, medium and feed platforms raised. The objective of the media was to ensure cell growth only in order to go as fast as possible to production bioreactors while the feeds were responsible for productivity and production length. Either companies spent several months if not years to develop their own generic medium and feed platforms or they used commercial ones, sometimes under licenses. The medium and feed platform assessment also started earlier in the product development process. Clone screening was performed more and more in fed-batch conditions rather than batch ones. Thus screening tools, scale-down models of bioreactors, with lower and lower working volumes were designed. Another cell culture process evolution was the development of new expression systems without any selection agents. In order to assess our screening scale-down model, between 20 to 35 chemically defined platforms from 9 suppliers were screened with $3 \mathrm{CHO}$ host cell lines/expression systems.

\section{Methods}

The following protocol was followed for 3 different $\mathrm{CHO}$ cell lines producing $\mathrm{mAb}$ :

- CHO host cell 1 - expression system $n^{\circ} 1: m A b$ I

* Correspondence: aurore.lahille@merckgroup.com Merck Biodevelopment, Martillac, France, 33650
- CHO host cell 1 - expression system $n^{\circ} 2:$ mAb II

- CHO host cell 2 - expression system n ${ }^{\circ} 3:$ mAb III

Each medium was prepared, supplemented according to cell requirements, $0.2 \mu \mathrm{m}$ PVDF filtrated and stored into at least 2 separated bottles. A sterility test was performed on each bottle before use. Each cell line was thawed and amplified during at least one week in its usual medium. Then the cells were adapted to each medium for at least 8 passages in either $125 \mathrm{~mL}$ shake flasks or $50 \mathrm{~mL}$ spin tubes in duplicate. Each media was preheated at $37^{\circ} \mathrm{C}$ before use and one bottle was used per duplicate in order to reduce contamination risk. After cell adaptation, fedbatch platform assessment was performed in $50 \mathrm{~mL}$ spin tubes at $37^{\circ} \mathrm{C}$ with a seeding density around $0.25 * 10^{6}$ viable cells $/ \mathrm{mL}$. Every 2 to 3 days, samples were taken to measure $\mathrm{pH}, \mathrm{pO}_{2}, \mathrm{pCO}_{2}$, viable cell density, viability, glucose and lactate levels. The feeding strategy applied was the same for each cell line and agreed with each supplier. The cultures were stopped when the viability was below $60 \%$ or after $16-17$ days.

\section{Results}

The objective of cell culture media is to sustain cell growth in order to quickly seed the production bioreactor. Here are the doubling times measured on the 3 cell lines (Table 1).

Despite having the same host cell, cell growth was different between $\mathrm{mAb}$ I and mAb II. The expression system could have a significant impact on cell growth behavior. In order to separate the different platform results, a color was assigned to each supplier and platform assessed (Figure 1).

Depending on the $\mathrm{CHO}$ host cell and the expression system, each platform had different performances. Some 
Table 1 Doubling time of each cell line in each medium after adaptation.

\begin{tabular}{llll}
\hline & mAb I & mAb II & mAb III \\
\hline Cellvento & $20 \mathrm{~h}$ CHO-200 medium & $23 \mathrm{~h}$ & $17 \mathrm{~h}$ \\
\hline Supplier A medium 1 & $20 \mathrm{~h}$ & $35 \mathrm{~h}$ \\
\hline Supplier A medium 2 & $20 \mathrm{~h}$ & $63 \mathrm{~h}$ & $22 \mathrm{~h}$ \\
\hline Supplier A medium 3 & $21 \mathrm{~h}$ & $24 \mathrm{~h}$ & $18 \mathrm{~h}$ \\
\hline Supplier B medium 1 & $20 \mathrm{~h}$ & $24 \mathrm{~h}$ \\
\hline Supplier B medium 2 & $24 \mathrm{~h}$ & $20 \mathrm{~h}$ \\
\hline Supplier C medium 1 & $26 \mathrm{~h}$ & $18 \mathrm{~h}$ \\
\hline Supplier C medium 2 & $22 \mathrm{~h}$ & $18 \mathrm{~h}$ \\
\hline Supplier D medium 1 & $21 \mathrm{~h}$ & $28 \mathrm{~h}$ \\
\hline Supplier E medium 1 & $26 \mathrm{~h}$ & $18 \mathrm{~h}$ \\
\hline Supplier E medium 2 & $23 \mathrm{~h}$ & $18 \mathrm{~h}$ & $17 \mathrm{~h}$ \\
\hline Supplier F medium 1 & $21 \mathrm{~h}$ & $19 \mathrm{~h}$ & $18 \mathrm{~h}$ \\
\hline Supplier G medium 1 & $21 \mathrm{~h}$ & $19 \mathrm{~h}$ \\
\hline Supplier G medium 2 & $20 \mathrm{~h}$ & $21 \mathrm{~h}$ \\
\hline Supplier G medium 3 & $26 \mathrm{~h}$ & $19 \mathrm{~h}$ \\
\hline Supplier G medium 4 & $20 \mathrm{~h}$ & $21 \mathrm{~h}$ \\
\hline Supplier H medium 1 & & $21 \mathrm{~h}$ \\
\hline Supplier H medium 2 & & \\
\hline
\end{tabular}

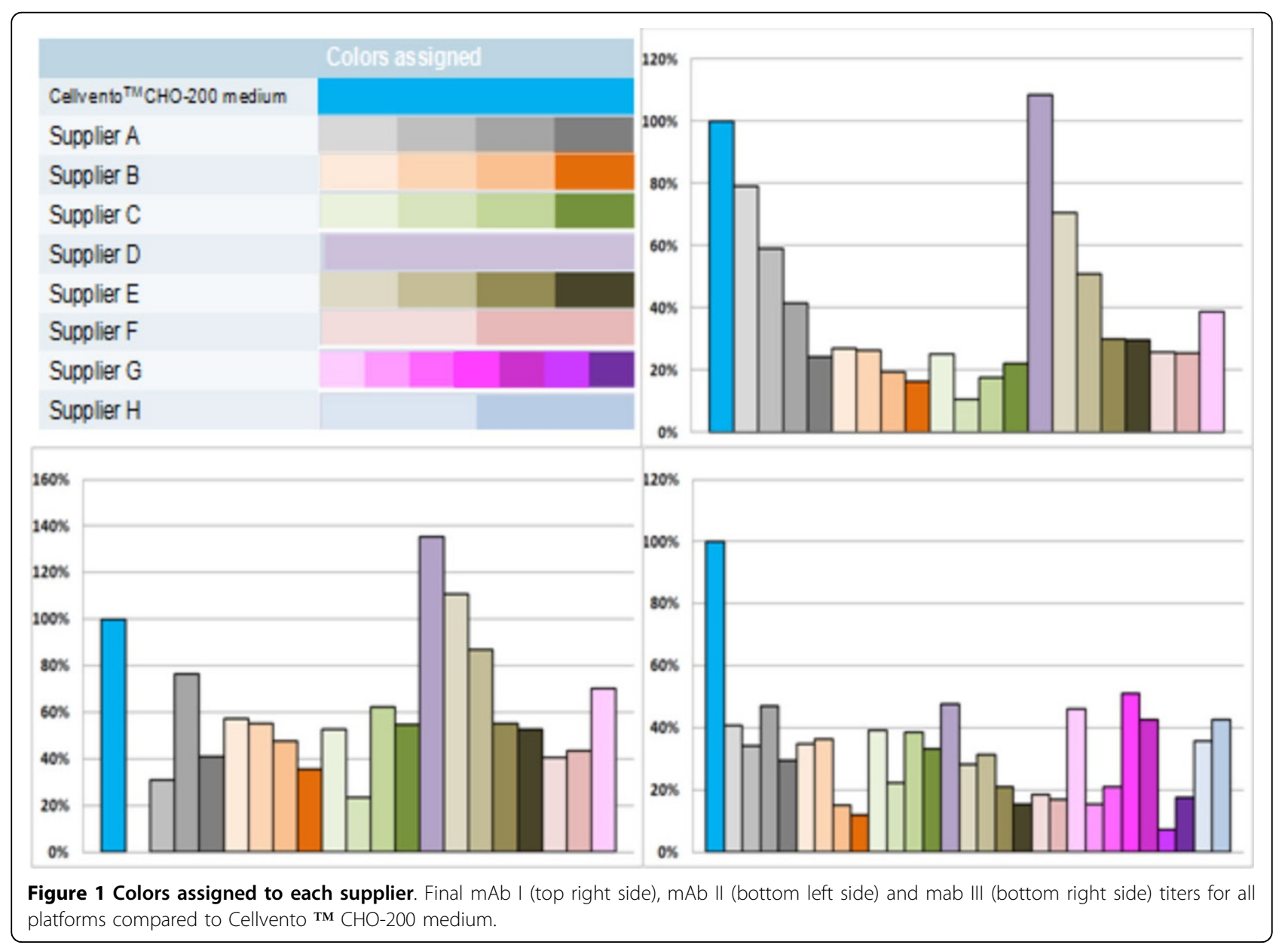


platforms seemed to be more robust than others in terms of final titer. The lactate metabolism was also compared between the different platforms. Most of the platforms had a maximum lactate concentration measured around $1-1.5 \mathrm{~g} / \mathrm{L}$. Some platforms went above $2 \mathrm{~g} / \mathrm{L}$ of lactate, which could be difficult to scale-up in bioreactors. The practical aspect was also studied as it can facilitate the implementation and the tech transfer. Some platforms assessed had 2 feeds added everyday while others only had 1 feed added 3 times. Molecule quality was also compared between platforms in terms of High Molecule Weight and cIEF.

\section{Conclusions}

We have implemented a strong protocol for medium and feed screening with up to 70 spin tubes manipulated in parallel. More than 3000 sterile manipulations were performed under a laminar flow without any contaminations. These experiments allow us to define robust platforms in terms of cell growth, productivity and metabolism on different $\mathrm{CHO}$ host cell lines and expression systems.

Published: 4 December 2013

doi:10.1186/1753-6561-7-S6-P100

Cite this article as: Polès-Lahille et al:: How to assess chemically defined media and feeds from 9 suppliers on $\mathrm{CHO}$ cells producing mAb. BMC

Proceedings 2013 7(Suppl 6):P100.
Submit your next manuscript to BioMed Central and take full advantage of:

- Convenient online submission

- Thorough peer review

- No space constraints or color figure charges

- Immediate publication on acceptance

- Inclusion in PubMed, CAS, Scopus and Google Scholar

- Research which is freely available for redistribution

Submit your manuscript at www.biomedcentral.com/submit 